Jurnal Interpretasi Hukum | ISSN: 2746-5047

Vol. 2, No. 3-Desember 2021, Hal. 555-561| Tersedia online di https://www.ejournal.warmadewa.ac.id/index.php/juinhum

DOI: https://doi.org/10.22225/juinhum.2.3.4136.555-561

\title{
PERLINDUNGAN HUKUM BAGI INVESTOR TERKAIT PEMBUBARAN BADAN HUKUM REKSA DANA
}

\author{
I Gede Satyawan Pradnya Wiguna, I Nyoman Budiartha, Desak Gde Dwi Arini \\ Fakultas Hukum, Universitas Warmadewa, Denpasar-Bali, Indonesia \\ satyapw156@gmail.com, budiathaputu59@gmail.com, arinidesak1966@gmail.com
}

\begin{abstract}
Abstrak
Reksadana adalah instrumen investasi diatur dalam peraturan nomor 23/POJK/04/2016 tentang reksa dana, sebagai pedoman bagi manajer investasi, melindungi hak para investor, kurang teliti investor dalam memilih produk reksadana dan menentukan manajer investasi yang tepat dan aman sehingga diperlukan perlindungan hukum Bagi Investor Reksa Dana. Tujuan penelitian ini untuk menganalisa akibat hukum bagi investor terkait pembubaran badan hukum reksa dana serta perlindungan hukum bagi investor reksa dana terkait pembubaran badan hukum reksa dana. Metode yang digunakan adalah penelitian hukum normatif dengan pendekatan perundang-undangan. Teknik pengumpulan bahan hukum dilakukan melalui studi pencatatan dan dokumentasi. Sumber bahan hukum primer dan sekunder digunakan sebagai sumber bahan-bahan hukum dalam studi ini. Kemudian, bahan dan data hukum tersebut dikelola dengan menggunakan analisis interpretasi. Hasil penelitian menunjukkan bahwa akibat hukum bagi investor terkait pembubaran badan hukum pengelola reksa dana diatur dalam pasal 50 Peraturan OJK jika produk reksa dana dibubarkan investor tidak dapat melakukan penjualan kembali setelah pembubaran produk reksadana, perlindungan bagi investor reksa dana terkait pembubaran badan hukum pengelola reksadana, apabila terjadi kerugian terhadap produk reksadana yang diakibatkan oleh manajer investasi, manajer investasi wajib bertanggung jawab atas kerugian karena tindakannya.
\end{abstract}

Kata Kunci: Investor, Perlindungan Hukum, Reksa Dana

\begin{abstract}
Mutual funds are investment instruments regulated in regulation number 23/POJK/04/2016 concerning mutual funds, as a guide for investment managers, protecting the rights of investors, investors are not careful in choosing mutual fund products and determining the right and safe investment manager so that legal protection is needed for Mutual Fund Investors. The purposes of this study are to analyze the legal consequences for investors related to the dissolution of a mutual fund legal entity and legal protection for mutual fund investors related to the dissolution of a mutual fund legal entity. The method used is normative legal research with a statutory approach. The technique of collecting legal materials is done through recording and documentation studies. Primary and secondary sources of legal materials are used as sources of legal materials in this study. Then, the legal materials and data are managed using interpretation analysis. The results of the study show that the legal consequences for investors related to the dissolution of the mutual fund managing legal entity are regulated in article 50 of the OJK Regulation if the mutual fund product is dissolved the investor cannot resell after the dissolution of the mutual fund product, protection for mutual fund investors is related to the dissolution of the mutual fund managing legal entity, if there is a loss to the mutual fund product caused by the investment manager, the investment manager must be responsible for the loss due to his actions.
\end{abstract}

Keywords: Investors, Legal Protection, Mutual Funds

\section{PENDAhUluAN}

Diera globalisasi permasalahan yang dihadapi pelaku bisnis menjadi sangat banyak terutama mengenai persaingan dengan para pelaku bisnis yang baru bermunculan sehingga pemerintah menggabungkan beberapa peraturan guna membatasi tindakan para pelaku bisnis tersebut yaitu dengan diterbitkannya Undang-undang mengenai Pasar Modal yaitu UU Nomor 8 Tahun 1995. Tempat guna mengumpulkan uang masyarakat yang akan dikembangkan oleh perusahan yang bergerak di bidang investasi untuk kepentingan bersama, baik itu swasta maupun pemerintah yang memerlukan dana dengan menerbitkan obligasi lalu menjualnya kepada pada para investor melalui pasar modal (Tavinayati \& Qamariyanti, 2009). Sebuah alternative yang dapat dipilih oleh masyarakat dalam berinvestasi adalah reska dana terutama bagi masyarakat yang baru ingin mencoba investasi 
dalam jumlah yang kecil dan relatif aman. Investasi dapat diartikan sebagai proses penembangan dana atau uang (Poerwadarminta, 1985). Sedangkan Sunariyah mengartikan investasi ialah suatu kegiatan penanaman modal dalam bentuk aktiva yang memiliki tenggang waktu yang cukup lama yang suatu saat akan mendapatkan suatu keuntungan pada akhirnya (Sunariyah, 2000).

Sebagai tempat berinvestasi suatu Reksadana dibutuhkan dalam memudahkan masyarakat saat berinvestasi di pasar modal/kapital. Reksa dana dibuat sang Manajer Bank Kustodian dengan sebuah akta kontrak kolektif yang dibentuk notaris. Dalam pengelola dana investasi yang terkumpul dari masyarakat atau investor buat diinvestasikan ke pada portofolio akan dikelola oleh manajer investasi, misalnya, obligasi, dan saham. Sementara itu yang memiliki posisi sebagai penyimpan dana atau portofolio adalah bank kustodian dan melakukan proses administrasi Reksa dana. Tempat berinvestasi bagi investor yaitu reksa dana dimana dapat berinvestasi ke beberapa instrumen investasi yang ada pada pasar. Investor tak perlu susah payah mengatur dan mengurus portofolionya sendiri. Tempat untuk berinvestasi yang dikelola oleh seorang manajer yang berbentuk saham, obligasi dan pasar uang dalam bentuk portofolio. Wadah seperti reksa dana merupakan bentuk pengelolaan dana dan juga sebagai modal awal investor dalam berinvestasi di berbagai instrumen pada pasar modal melalui pembelian unit penyertaan reksa dana. Reksa dana dapat meminimalisir peran pemodal asing karena reksa dana sebagai yang dipilih masyarakat dalam menghimpun dana. Dimana kita ketahui bersama bahwasanya pemodal asing sangat dominan dalam perdagangan di bursa efek. Karena pada dasarnya keadaan ketahanan pasar Indonesia berada di bawah kendali mereka. Masyarakat sangat membutuhkan reksa dana bukan saja dalam investasi namun juga reksadana sebagai Trilogi yang mendukung keberhasilan Ketahanan Nasional di bidang Pasar Modal Indonesia Pembangunan. (Usman, 1999). Cara berinvestasi yang mudah bagi masyarakat dan pelengkap berinvestasi lewat reksadana karena bentuk investasi ini bukan dikeluarkan oleh perusahaan maupun bank. Selain itu sebagai wadah dan transportasi masyarakat dalam berinvestasi dalam bentuk saham, obligasi dan bukan deposito.

Suatu instrumen untuk memposisikan uang atau harta kekayaan dalam bentuk modal untuk mendapatkan keuntungan atau hasil yang lebih dengan membeli saham, obligasi properti dan lainlain. Berinvestasi dapat dikatakan sebagai kegiatan meluangkan pikiran waktu dan tenaga untuk mendapat keuntungan di masa mendatang. Berdirinya suatu perusahan investasi dapat dipicu karena kesulitan masyarakat dalam usaha memulai berinvestasi sehingga perusahaan ini akan membantu masyarakat dalam berinvestasi dan mengurus surat-surat berharga. Berinvestasi di pasar modal dapat mendatangkan manfaat maupun keuntungan dari sifat likuiditas dari investasi ini. Dimana Investor dapat memiliki sekuritas yang akan memberi return yang baik dan menjual sekuritas ini pada saat memerlukan dana atau juga bisa menggantinya dengan sekuritas lain bila prospek sekuritas lain lebih menguntungkan. Selain itu setiap investor dapat melakukan diversifikasi dengan menanamkan dananya pada jenis sekuritas yang berbeda (Tandelilin, 2001). Investor biasa melakukan kegiatan/aktivitas investasi menggunakan tujuan buat memperoleh return yang lebih memuaskan berdasarkan dalam risiko yang dihadapinya dan lebih tinggi berdasarkan investasi dalam aset yang bebas risiko. Investasi dalam aset yang bebas risiko sebagai baku minimal berdasarkan apa yang akan diperoleh apabila melakukan investasi dalam saham. Tentu saja tujuan akhir berdasarkan investor melakukan investasi dalam saham merupakan buat menaikkan kemakmuran hidupnya. Selanjutnya para investor wajib mengelola dananya secara efektif menggunakan berusaha membeli saham-saham yang mempunyai risiko yang masih bisa diterima sebagai akibatnya return yang akan diterima masih melebihi risiko yang dihadapi. Untuk meminimalisir risiko dalam investasi, seseorang investor wajib acap kali melakukan diversifikasi pada investasi mereka.

Investor pula wajib mengkombinasikan banyak sekali sekuritas pada investasi buat meminimalkan risiko yang kemungkinan akan muncul. Diversifikasi dalam investasi menciptakan investor bisa meminimalkan risiko menggunakan permanen memperhatikan return yang diterima. Bentuk konkret diversifikasi risiko galat satunya merupakan Reksa dana. Walaupun reksa dana tidak berbentuk badan hukum, tetapi menjadi sebagai tempat investasi dengan mempunyai ciri khas dipisahkan harta berdasarkan pendiri dan yang menjalankan usahanya, sebuah reksa dan Kontrak Investasi Kolektif (KIK) mempunyai peluang buat bubarkan dan harta para pendiri dan yang mengelolah tidak dapat diminta pertanggungjawabannya buat menganti kerugian yang dialami para investor. Sebab itu, para investor wajib mempunyai keyakinan terhadap pengelola reksa dana (KIK) 
dan juga pengelola reksa dana Kontrak Investasi Kolektif (KIK) wajib mempunyai itikad baik, profesionalisme dan terbuka terhadap pemilik dana yang di investor, terutama pada menaruh berita pada warga pemodal. Namun pada pada hal ini risiko kerugian yang dialami investor baik yang ditimbulkan dari manajemen pengelolaan investasi yang sudah dilakukan dengan professional juga kekeliruan atau tindakan lalai manajer investasi saat pengelolaan produk reksa dana. produk tidak dijamin oleh pemerintah sebagai produk perbankan dengan bentuk simpanan yang bergantung pada pengendalian suku bunga perbankan pemerintah dan adanya agunan terhadap aset nasabah simpanan dari Lembaga Penjamin Simpanan (LPS). Dengan demikian sangat tinggi peluang terjadinya tindak pidana, PMH dan wanprestasi pada pengelolaan reksa dana. Akibatnya terjadi keadaan yang merugikan dan bila investor tidak mengetahui hal tadi, sebagai akibatnya investor mampu terlambat pada merogoh keputusan buat mengambil tindakan yang dapat mengamankan investasinya, contohnya menggunakan menarik dana miliknya berdasarkan Reksa dana (Hadisoeprapto, 1996).

Teori perundang-undangan terdiri berdasarkan teori perundang-undangan dan tata urutan pembentukannya yang relevan menggunakan stufenbau theorie (Atmadja, I Dewa Gede Budiartha, 2018). Pembubaran reksa dana diatur pada pasal 45 peraturan otoritas jasa keuangan angka 23/POJK/04/2016 mengenai reksa dana berbentuk kontrak investasi kolektif, suatu produk reksa dana akan dibubarkan bila pada waktu 90 hari bursa reksa dana yang baru menerima pernyataan efektif dana yang dikelolanya kurang berdasarkan 10 milyar rupiah atau buat reksadana menggunakan penjaminan, reksa dana yg terproteksi, reksa dana indeks menggunakan penawaran terbatas yg produk reksa dana tadi sudah berjalan bila pada saat 120 hari bursa berturut-turut sehabis pernyataan registrasi reksa dana sebagai efektif dana yang dikelolanya wajib mencapai 10 milyar rupiah. Selain kondisi tadi reksa dana bisa dibubarkan bila diperintahkan sang otoritas jasa keuangan menggunakan peraturan perundang-undangan terkait pasar kapital dan bila sudah terjadi konvensi antara pihak manajer investasi dan pihak bank kustodian terkait menggunakan pembubaran reksa dana. Maka dari itu penelitian ini begitu krusial dilaksanakan menimbang masih sering warga pendaftar produk reksa dana yang belum mengetahui dan tahu aspek aturan yang terjadi dalam pengelola reksa dana, terutama nasabah pemilik unit penyertaan menjadi pemilik kapital (investor) yang paling berpotensi mengalami kerugian. Maka untuk itu diperlukan suatu perlindungan hukum bagi para investor reksa dana terkait pembubaran badan hukum pengelola reksa dana tempat investor menanamkan modalnya.

Adapun penelitian sebelumnya dari Permana \& Artha (2018) menyatakan bahwa perlindungan hukum terhadap investor yang terdapat dalam UUPM dan POJK APERD belum memberikan kepastian hukum dalam hal bentuk dan besaran ganti rugi yang didapat investor yang dimuat dalam Pasal 111 UUPM dan Pasal 34 POJK APERD sehingga menyebabkan kekaburan norma. Sedangkan menurut Asriati \& Baddu (2021) bentuk perlindungan hukum terhadap konsumen dilakukan secara preventif dan represif oleh OJK. Lebih lanjut, Hartanto (2014) mengungkapkan secara umum, pemegang Unit Penyertaan selaku konsumen reksa dana selain memiliki hak sebagaimana diatur pada peraturan Bapepam LK atau OJK. Dari fenomena tersebut maka dilakukannya penelitian yang bertujuan untuk menganalisa akibat hukum bagi investor terkait pembubaran badan hukum reksa dana serta perlindungan hukum bagi investor reksa dana terkait pembubaran badan hukum reksa dana.

\section{METODE PENELITIAN}

Penelitian ini menggunakan tipe penelitian hukum normatif yang meletakan aturan menjadi bangunan sistem norma sebagai metode penelitian dalam studi ini yakni mengenai asas-asas hukum, doktrin, norma-norma, kaidah-kaidah terhadap suatu peraturan perundang-undangan. Adapun tipe pendekatan yang diaplikasikan yaitu pendekatan perundang-undangan. Peneliti mengumpulkan bahan hukum yang diperlukan melalui studi pencatatan dan dokumentasi. Sumber bahan hukum yang digunakan adalah bahan hukum primer yaitu peraturan perundang-undangan, dan bahan hukum sekunder seperti literature. Bahan hukum yang telah berhubungan dengan permasalahan telah terkumpul. Kemudian, bahan dan data hukum tersebut dikelola dengan menggunakan analisis interpretasi. hukum agar dapat menjawab permasalahan yang dibahas. 


\section{HASIL DAN PEMBAHASAN}

\section{Akibat Hukum Bagi Investor Terkait Pembubaran Badan Hukum Reksa Dana}

Akibat Hukum bagi investor terkait pembubaran badan hukum reksa dana, Dana yang di peroleh dari masyarakat akan di investasikanke berbagai efek dan di perdagangkan di pasar uang ataupun pasar modal dengan diterbitkanya unit penyertaan pada masyarakat. dalam berinvestasi di reksa Dana adalah Risiko Pembubaran mungkin saja terjadi. Apabila suatu Reksa Dana dibubarkan, maka tidak akan mengakibatkan Manajer Investasinya ikut bubar. Sebab Reksa Dana ini merupakan sebuah produk manajer investasi yang menjadi pengembang dana Reksa Dana adalah entitas yang sama sekali berbeda. Satu Manajer Investasi dapat mengelola beberapa produk Reksa Dana, dan jika salah satu produk Reksa Dana tersebut dibubarkan, maka tidak akan otomatis menyebabkan Manajer Investasinya ikut bubar pula. Antara kekayaan yang dimiliki oleh Reksa Dana dengan kekayaan yang dimiliki oleh Manajer Investasi maupun kekayaan yang dimiliki oleh Bank Kustodian adalah terpisah dan masing-masing memiliki pembukuan sendiri. Reksa Dana yang memiliki harta kekayaan tidak bisa di sita begitu saja, jika seorang manajer investasi dan/atau Bank kustodian mengalami Pailit Jika terjadi Pembubaran dan Likuidasi suatu Reksa Dana, maka pihak yang paling dirugikan adalah Investor Pemegang Unit Penyertaan. Yang diatur dalam pasal 50 Peraturan OJK mengenai Reksadana menjelaskan bahwa apabila produk reksadana telah dibubarkan maka investor reksadana tidak dapat melakukan penjualan kembali setelah pengumuman mengenai pembubaran produk reksadana. Sebab akibat dari dibubarkannya Reksa Dana tersebut maka harapan Investor Pemegang Unit Penyertaan untuk memperoleh keuntungan dari investasinya akan sirna. Selain itu, Investor akan memperoleh hasil Likuidasi terkadang nilainya jauh lebih kecil dari dananya semula yang diinvestasikan di reksadana (output lebih kecil dari input).

Saat di Likuidasi Reksa Dana, maka yang bertindak sebagai Likuidator adalah dalam mengelola Reksa Dana tersebut yakni manajer investasi. Tugas utama manajer investasi adalah membagi hasil likuidasi secara seimbang berdasarkan sama rata bagian dari Unit Penyertaan yang dikuasai pemegang Unit Penyertaan masing-masing. Jika yang diperoleh akibat Likuidasi Reksa Dana tersebut tidak mencukupi untuk dibagikan kepada pemegang Unit, maka berapapun kecilnya perolehan Likuidasi Reksa Dana ini tetap harus dibagikan kepada pemegang Unit Penyertaan secara seimbang dikurangi beban-beban yang merupakan kewajiban Reksa Dana sebagaimana telah disebutkan di atas. Pengaturan yang demikian dapat merugikan Investor Pemegang Unit Penyertaan. Karena berdasarkan ketentuan yang terdapat didalam Pasal 25 Kontrak Investasi Kolektif menyatakan bahwa Reksa Dana Kontrak Investasi Kolektif dapat dibubarkan apabila Nilai Aktiva Bersihnya menjadi kurang dari Rp2.500.000.000,00 (dua milyar lima ratus juta rupiah)selama 90 (sembilan puluh)hari bursa berturut-turut -turut. Jika Nilai Aktiva Bersih tersebut digunakan untuk memenuhi 7 (tujuh) beban-beban yang harus dipenuhi oleh Reksa Dana sebagaimana disebutkan diatas dan dibagikan ke para Investor Pemegang Unit Penyertaan sebagai hasil Likuidasi,maka Nilai Aktiva Bersih tersebut pasti akan habis tanpa sisa atau jika masih ada sisa pasti nilainya sangat kecil sekali dan tidak akan dibagikan kepada semua Investor Pemegang Unit Penyertaan tersebut.

Apabila Investor Pemegang Unit Penyertaan dirugikan, maka Investor tersebut dapat menuntut ganti rugi. Kerugian yang disebabkan oleh Manajer Investasi dan/atau Bank Kustodian baik bagi Pemerintah atau agi perusahan yang membutuhkan dana menggunakan surat berharga yakni saham, obligasi dan surat berharga yang lainnya, yang menjadi sarana investasi ReksaDana) yang menyebabkan terjadinya kerugian tersebut. Di Dalam Ketentuan Pasal 111 UU Nomor mengenai Pasar Modal menjamin perlindungan hukum bagi setiap pihak yang merasa dirugikan akibat adanya peraturan Pasar Modal. Ketentuan Pasal tersebut dapat digunakan sebagai dasar untuk mengajukan gugatan gugatan. Ketentuan mengenai Pertanggungjawaban yang terdapat didalam pasal tersebut adalah sangat luas, karena tidak disebutkan secara spesifik perbuatan-perbuatan yang ditentang oleh para pihak tertentu tetapi memperlihatkan kepada tiap-tiap pelanggaran terhadap UU Nomor 8 tahun 1995 mengenai Pasar Modal Dan peraturan lainya. Jika yang menyebabkan kerugian tersebut adalah Manajer Investasi dan/atau Bank Kustodian, maka Investor Pemegang Unit Penyertaan Reksa Dana tersebut dapat mengajukan gugatan perdata dan ganti rugi terlebih dahulu serta dapat menyelesaikan sengketanya terlebih dahulu. Jika setelah 60 (enam puluh) hari perdamaian antara Pemegang Unit Penyertaan dengan Manajer Investasi dan/atau Bank Kustodian tidak tercapai, maka penyelesaian selanjutnya dilaksanakan melalui Badan Arbitrase Pasar Modal Indonesia dan jika yang menyebabkan 
kerugian adalah pihak lain, baik Pemerintah atau Perusahaan yang membutuhkan dana investasi melalui penerbitan surat berharga yaitu saham, obligasi dan lainnya yang menjadi sarana investasi ReksaDana), maka Investor Pemilik Unit Penyertaan dapat mengajukan gugatan perdata dan ganti rugi kepada yang dianggap dapat bertanggung jawab akibat terjadinya kerugian. Gugatan ini dapat diajukan kepada Badan Peradilan Umum maupun kepada Badan Arbitrase yang sudah di setujui oleh Investor pemegang Unit Penyertaan Reksa Dana tersebut dengan orang-orang yang telah mengakibatkan terjadinya kerugian itu.

Apabila Manajer Investasi melarikan diri dari tanggung jawabnya sebagai yang menangani tata kelola Reksa Dana maka Bank Kustodian ikut bertanggung jawab atas Reksa Dana yang dikelola oleh Manajer Investasi tersebut. Investor Pemegang Unit Reksa Dana tersebut yang dirugikan dapat menggugat Bank Kustodian dengan dasar Pasal 3 yang terdapat di dalam Kontrak Investasi Kolektif. Menurut Pasal ketentuan tersebut Manajer Investasi dan Bank Kustodian semuanya mengikatkan diri pada para Investor Unit Penyertaan dan masing-masing juga berjanji untuk melaksanakan sebaik mungkin kepentingan Investor Unit Penyertaan. Jika Manajer Investasi adalah tanggung jawab Bank, maka Bank Kustodian dianggap tidak melaksanakan dengan baik dalam pelaksanaan Pengawasan Intern kepada Manajer Investasi tersebut. Yang dimaksud dengan Pengawasan Intern adalah pengawasan secara sistem yang dilaksanakan melalui Kontrak Kolektif yang memisahkan fungsi penyimpanan milik Bank Kustodian dan fungsi Pengelolaan milik Manajer Investasi ,dimana masingmasing pihak dapat saling mengontrol dan mengawasi untuk mengetahui apakah pihak lawan kontraknya sudah menjalankan semua kewajiban tertulis dalam Kontrak Investasi Kolektif tersebut. Adapun Argumentasi yang dapat penulis sampaikan mengenai Akibat hukum investor reksa dana terkait pembubaran badan hukum pengelola reksa dana menurut pasal 50 Peraturan No.23/POJK.04/2016 mengenai Reksadana Kontrak Investasi Kolektif menjelaskan bahwa apabila reksadana telah dibubarkan maka investor reksadana tidak dapat melakukan penjualan kembali setelah pengumuman mengenai pembubaran reksadana. Menurut pasal 46 huruf c dijelaskan bahwa reksadana wajib dibubarkan paling lambat 10 hari bursa sejak berakhirnya jangka waktu sebagaimana yang diatur dalam pasal 45 huruf a dan b. Meskipun demikian bentuk perlindungan hukum bagi investor reksa dana terkait pembubaran badan hukum pengelola reksa dana diatur dalam Pasal 27 ayat 2 Undang-undang Pasar Modal menjelaskan bahwa apabila terjadi kerugian terhadap suatu reksadana yang diakibatkan oleh manajer investasi, maka segala kerugian yang timbul menjadi tanggung jawab manajer investasi.

\section{Serta Perlindungan Hukum Bagi Investor Reksa Dana Terkait Pembubaran Badan Hukum Reksa Dana}

Perlindungan yang diberikan oleh hukum bagi investor Reksa dana yaitu jaminan yang terhadap norma, kaedah, peraturan, hukum positif dilekatkan kepada orang atau badan usaha. Dimana orang atau badan usaha yang membeli suatu produk investasi dan menanamkan modalnya dengan bantuan jasa penitipan kustodian melalui perbankan. dimana OJK bertanggung jawab secara langsung pada Menteri Keuangan. OJK juga yang memiliki wewenang guna menjamin perlindungan pasar modal yang bersifat preventif maupun represif. Perlindungan secara Preventif adalah salah satu bentuk Perlindungan dijalankan pemerintah untuk tujuan pencegahan sebelum terjadinya suatu pelanggaran. Pada peraturan perundang-undangan sebenarnya sudah diatur dengan harapan mencegah pelanggaran dan sebagai batasan-batasan dalam melakukan suatu kewajiban dalam rambu-rambu tertentu. Bentuk Perlindungan hukum yang bersifat preventif terhadap investor reksa dana sebagaimana diatur dalam Pasal 65 Peraturan OJK Tentang Reksadana KIK adapun normanya adalah manajer investasi wajib memastikan investor reksadana telah menerima dan memastikan calon investor reksadana telah membaca isi dari prospektus reksa dana sebelum membeli produk reksadana. Perlindungan terhadap investor dalam hukum preventif bisa dengan melakukan tindakan keterbukaan informasi. Ini merupakan bentuk perlindungan mendasar selain larangan manipulasi yang diatur Pasal 90 sampai 99 UUPM serta keahlian dari manajer investasi saat mengelola dana milik investor, yang merupakan hal wajib untuk dijalankan oleh perusahaan public adalah keterbukaan informasi. Yang berartinya, perusahaan publik yang telah menerima dana publik yaitu investor reksa dana serta beberapa sahamnya milik public sebab itu, perusahaan menjadi wajib untuk bersikap terbuka kepada semua pihak yang memerlukan informasi berkaitan kinerja perusahaan itu. 
Bentuk Perlindungan Represif yaitu upaya hukum terakhir yang dijamin oleh hukum yang berbentuk sanksi yaitu denda, penjara, dan hukuman tambahan yang diberikan setelah sengketa telah terjadi atau telah dilakukan suatu pelanggaran. Apabila kesepakatan penyelesaian secara Pengaduan tidak dapat tercapai, Penyelesaian Sengketa sebagaimana diatur lebih lanjut pada Penyelesaian Sengketa di pengadilan dapat dilakukan oleh Pemegang Unit Penyertaan dan Manajer Investasi dan/atau Bank Kustodian dan/atau Dealer Partisipan yaitu Penyelesaian Sengketa dapat menggunakan Peraturan dan Acara BAPMI dan tunduk pada Undang-undang Nomor 30 Tahun 1999 mengenai Arbitrase dan Alternatif Penyelesaian Sengketa dan peraturan terkait lainya melalui Badan Arbitrase Pasar Modal Indonesia (BAPMI). Berdasarkan kedua macam perlindungan hukum ini pada umumnya dimaksudkan untuk melindungi hak-hak subyek hukum yang dilanggar dengan cara mengajukan keberatan dan mengajukan pendapatnya kepada pemerintah serta memberikan hak kepada warga negara untuk mengajukan tuntutan kepada lembaga peradilan yang berwenang. Pendapat penulis berkenaan dengan upaya preventif dan represif adalah upaya pertama yang dapat ditempuh oleh pihak manajer investasi untuk mencegah terjadinya masalah di kemudian hari. Upaya yang dilakukan untuk mencegah terjadinya masalah menjadi preventif yaitu dengan mengalikan norma-norma atau nilainilai yang baik yang mana norma tersebut terinternalisasi dalam pribadi manusia secara sendirinya. Walaupun masih memungkinkan untuk dilakukannya pelanggaran namun niatnya tersebut untuk melakukan tidak akan terjadi pelanggaran atau kelalaian. faktor niat menjadi hilang dalam upaya hukum preventif meskipun kesempatan tetap ada. yang ditekankan dalam upaya preventif adalah meniadakan kesempatan untuk dilakukannya pelanggaran atau kelalaian. Jika setelah dicegah gangguan nyata masih terjadi maka, dari sinilah harus diambil sikap Penegakan Hukum, hal inilah yang dapat disebut dengan upaya Represif. Dimana upaya represif berupa proses tindakan yang dilakukan bagi manajer investasi yang menentang peraturan yang berlaku dan diproses secara hukum lalu dihukum dengan sanksi sesuai dengan ketentuan UU.

\section{SIMPULAN DAN SARAN}

\section{Simpulan}

Akibat hukum investor reksa dana terkait pembubaran badan hukum pengelola reksadana, Pembubaran dan Likuidasi Reksa Dana dapat dikatakan sebagai resiko dan akibat yang bisa saja terjadi. Kerugian yang dialami Investor Pemegang Unit Penyertaan akibat pembubaran tersebut bisa meminta pertanggung jawaban kepada pihak-pihak Manajer Investasi atau Bank Kustodian atau Pihak-pihak lain yang bersangkutan yang menyebabkan kerugian bagi investor. Bentuk perlindungan dari hukum bagi investor reksa dana terkait pembubaran badan hukum reksa dana ada dua bagian, yakni perlindungan preventif dan perlindungan hukum secara represif. Perlindungan hukum yang bersifat preventif terhadap investor reksa dana sebagaimana diatur dalam Pasal 65 Peraturan Otoritas mengenai Kontrak Investasi Kolektif Reksa dana. Sedangkan perlindungan hukum represif bagi investor diatur pada peraturan Nomor 2/SEOJk.07/2014 mengenai Pelayanan dan Penyelesaian Pengaduan Konsumen Pada Pelaku Usaha Jasa Keuangan dan Pasal apabila produk reksadana dibubarkan tetapi terdapat pihak yang melakukan wanprestasi adalah investor dapat meminta tanggung jawab dalam bentuk penggantian kerugian yang diatur dalam Undang-undang.

\section{Saran}

Bagi masyarakat khususnya Calon investor sebelum berinvestasi dalam bentuk reksa dana, masyarakat sebagai seorang calon investor harus teliti dalam memahami dan mengerti terlebih isi dari prospectus. reksadana dalam melakukan pembelian produk reksadana, karena prospektus tersebut berisi informasi lengkap mengenai produk reksadana dan yang lebih penting investor reksadana dapat mengetahui rekam jejak manajer investasi dan kondisi keuangan dari produk reksadana tersebut. Bagi Manajer Investasi sebagai pihak yang dipercaya pengelolaan reksadana seharusnya menjalankan tugas dan kewajibannya sesuai dengan ketentuan Peraturan OJK agar manajer investasi tidak merugikan para investor reksadana, karena dalam Undang-undang Pasar Modal diatur Pasal 27 ayat 2 menyebutkan bahwa apabila terjadi kerugian terhadap produk reksadana yang diakibatkan oleh manajer investasi, maka kewajiban bertanggung jawab atas segala kerugian yang timbul menjadi milik manajer investasi. Saran bagi OJK yang mempunyai wewenang pada pengaturan serta pengawasan mengenai kegiatan di sektor jasa keuangan seperti pada perasuransian, lembaga 
pembiayaan, pasar modal dan lembaga jasa keuangan lainnya hendaknya harus dapat menjamin keadilan, kepastian, kemanfaatan dari produk hukum yang diterbitkan.

\section{DAFTAR PUSTAKA}

Asriati, \& Baddu, S. (2021). Investasi Online Reksadana: Aspek Hukum dan Perlindungan Bagi Investor selaku Konsumen. PLENOJURE: Jurnal Ilmu Hukum, 10(1), 38-53.

Atmadja, I Dewa Gede Budiartha, I. N. P. (2018). Teori-teori Hukum. Setara Press, Malang.

Hadisoeprapto, H. (1996). Pokok-pokok Hukum Perikatan dan Hukum Jaminan. Liberty, Yogyakarta.

Hartanto, R. (2014). Perlindungan Hukum Terhadap Pemegang Unit Penyertaan Dalam Reksadana. Jurnal Hukum Bisnis, 33(4), 366-377.

Permana, I. G. M. A., \& Artha, I. G. (2018). Perlindungan Hukum Terhadap Investor Dalam Reksadana Secara Online. Kertha Semaya, 6(9), 1-16.

Poerwadarminta, W. J. S. (1985). Kamus Bahasa Indonesia. Balai Pustaka, Jakarta.

Sunariyah. (2000). Pengantar Pengetahuan Pasar Modal. UPP YKPN, Makassar.

Tandelilin, E. (2001). Analisis Investasi dan Manajemen Portofolio. BPFE, Yogyakarta.

Tavinayati, \& Qamariyanti, Y. (2009). Hukum Pasar Modal di Indonesia. Sinar Grafika, Jakarta.

Usman, M. (1999). Bunga Rampai Reksa Dana. Balai Pustaka, Jakarta. 